\title{
Lactobacillus delbrueckii UFV-H2b20 induces type 1 cytokine production by mouse cells in vitro and in vivo
}

\author{
E. Neumann ${ }^{1}$, M.G. Ramos ${ }^{1}$, L.M. Santos ${ }^{1}$, A.C.P. Rodrigues ${ }^{1}$, E.C. Vieira ${ }^{1}$, \\ L.C.C. Afonso ${ }^{3}$, J.R. Nicoli ${ }^{2}$ and L.Q. Vieira ${ }^{1}$
}

${ }^{1}$ Departamento de Bioquímica e Imunologia, ${ }^{2}$ Departamento de Microbiologia, Instituto de Ciências Biológicas, Universidade Federal de Minas Gerais, Belo Horizonte, MG, Brasil 32Departamento de Ciências Biológicas, Núcleo de Pesquisas em Ciências Biológicas, Instituto de Ciências Exatas e Biológicas, Universidade Federal de Ouro Preto, Ouro Preto, MG, Brasil

Correspondence to: L.Q. Vieira, Departamento de Bioquímica e Imunologia, Instituto de Ciências Biológicas, UFMG, Caixa Postal 486, 30161-970 Belo Horizonte, MG, Brasil

Fax: +55-31-3409-2614. E-mail: Iqvieira@icb.ufmg.br

Lactobacillus delbrueckii UFV-H2b20 has been shown to increase clearance of bacteria injected into the blood of germ-free mice. Moreover, it induces the production of type 1 cytokines by human peripheral mononuclear cells. The objective of the present study was to investigate the production of inflammatory cytokines [interleukin-12 (IL-12 p40), tumor necrosis factor- $\alpha$ (TNF- $\alpha$ ), and interferon- $\gamma$ (IFN- $\gamma$ )] triggered in vitro by live, heat-killed or lysozyme-treated $L$. delbrueckii UFV-H2b20 and in vivo by a live preparation. Germ-free, L. delbrueckii-monoassociated and lipopolysaccharide (LPS)-resistant $\mathrm{C} 3 \mathrm{H} / \mathrm{HeJ}$ mice were used as experimental models. UFV-H2b20 induced the production of IL-12 p40 and TNF- $\alpha$ by peritoneal cells and IFN- $\gamma$ by spleen cells from germ-free or monoassociated Swiss/ $\mathrm{NIH}$ mice and LPS-hyporesponsive mice (around $40 \mathrm{ng} / \mathrm{mL}$ for IL-12 p40, $200 \mathrm{pg} / \mathrm{mL}$ for TNF- $\alpha$ and $10 \mathrm{ng} / \mathrm{mL}$ for IFN- $\gamma$ ). Heat treatment of $L$. delbrueckii did not affect the production of these cytokines. Lysozyme treatment decreased IL-12p40 production by peritoneal cells from $\mathrm{C} 3 \mathrm{H} / \mathrm{HeJ}$ mice, but did not affect TNF- $\alpha$ production by these cells or IFN- $\gamma$ production by spleen cells from the same mouse strain. TNF- $\alpha$ production by peritoneal cells from Swiss/ $\mathrm{NIH}$ L. delbrueckii-monoassociated mice was inhibited by lysozyme treatment. When testing IL-12 p40 and IFN- $\gamma$ levels in sera from germ-free or monoassociated Swiss/NIH mice systemically challenged with Escherichia coli we observed that IL-12 p40 was produced at marginally higher levels by monoassociated mice than by germ-free mice (40 vs $60 \mathrm{ng} / \mathrm{mL})$, but IFN- $\gamma$ was produced earlier and at higher levels by monoassociated mice (monoassociated 4 and $14 \mathrm{ng} / \mathrm{mL} 4$ and 8 h after infection, germfree 0 and $7.5 \mathrm{ng} / \mathrm{mL}$ at the same times). These results show that $L$. delbrueckii UFV-H2b20 stimulates the production of type 1 cytokines in vitroand in vivo, therefore suggesting that $L$. delbrueckii might have adjuvant properties in infection in which these cytokines play a major role.

Key words: Probiotics; Cytokines; Macrophages; IFN- $\gamma$; IL-12; Lactobacillus

Research supported by FAPEMIG (CBB\#2818/97 and\#2409/03). E.C. Vieira, L.C.C. Afonso, J.R. Nicoli, and L.Q. Vieira are recipients of CNPq fellowships and E. Neumann, M.G. Ramos, L.M. Santos, and A.C.P. Rodrigues are recipients of CAPES doctorate fellowships.

Received March 4, 2008. Accepted January 6, 2009

\section{Introduction}

There is growing interest in probiotics as modulators of the immune response to infections and autoimmune diseases (1-6). Probiotics are defined by the United Nations Food and Agricultural Organization and the World Health Organization as "live microorganisms, which when administered in adequate amounts, confer a health benefit on the host" (FAO/WHO 2001). In recent years, there have been many efforts to obtain microorganisms suitable to be used as probiotics (2).

Various health improvement claims have been associated with putative probiotic microorganisms in both man and animals and three characteristics were proposed to 
be desirable for selecting an effective probiotic: 1) promotion of resistance to colonization by pathogens; 2) influence on metabolic activities of the microbiota related to host health; 3) stimulation of the host immune response $(1,2)$. A number of investigations suggest that lactic acid bacteria, which include the majority of currently used probiotics, stimulate several functions of the immune system such as peritoneal macrophage activity and antibody and cytokine production (7-10). Pro-inflammatory cytokines such as tumor necrosis factor- $\alpha$ (TNF- $\alpha$ ), interleukin-1 $\beta$ (IL-1 1 ) and IL-6, as well as interferons, are among the first cytokines produced in response to pathogenic bacteria. Cytokines produced later during microbial infection direct responses toward either T-helper type 1 (Th1) or Th2 type immunity. Type 1 cytokines include macrophage- and dendritic cell-derived IL-12 and natural killer (NK)- and T-cell-derived interferon- $\gamma$ (IFN- $\gamma$ ) (11). IL-12 stimulates IFN- $\gamma$ production by NK and naive CD4 ${ }^{+} \mathrm{T}$ cells, which differentiate into the Th1 subtype. IFN- $\gamma$ enhances IL-12 production by phagocytic cells and down-regulates Th2 type cell proliferation and activation (11). The term "type 1 cytokines" refers to cytokines derived from CD4+ T cells of the Th1 subtype, as well as other pro-inflammatory cytokines, such as TNF- $\alpha$ and IL-12.

In the present study, we determined the ability of intact, heat-killed or lysozyme-treated Lactobacillus delbrueckii UFV-H2b20 to induce type 1 cytokine production by gnotobiotic and conventional mouse cells. This strain of Lactobacillus was first identified as $L$. acidophilus, a normal inhabitant of the human intestinal tract, designated $L$. acidophilus UFV-H2b20. This strain was isolated from feces of a newborn child at Universidade Federal de Viçosa (Viçosa, MG, Brazil). This strain resists the stressing conditions of the gastrointestinal tract both in vitro (12) and in vivo (13). Further PCR analysis followed by sequencing classified this strain as $L$. delbrueckii var. bulgaricus (14). We have shown that this strain of $L$. delbrueckii var. bulgaricus stimulates the phagocytic capacity of macrophages in monoassociated Swiss mice, as demonstrated by clearance of a Gram-negative bacterium inoculated intravenously (13). However, the effect that $L$. delbrueckii might have on cytokine production in response to a systemic infection was not determined. Therefore, we also analyzed the production of type 1 cytokines by mice monoassociated with $L$. delbrueckii after systemic challenge with Escherichia coli.

\section{Material and Methods}

Animals and microorganisms

Four distinct murine models were employed: Swiss/
NIH germ-free mice, Swiss/NIH conventional (microbiotabearing) mice, ex-germ-free mice that were monoassociated with $L$. delbrueckii as described in the next item, and $\mathrm{C} 3 \mathrm{H} / \mathrm{HeJ}$ (microbiota-bearing) mice, which are resistant to lipopolysaccharide (LPS). Germ-free Swiss/NIH mice were maintained at the Gnotobiology and Immunology Laboratory of the Department of Biochemistry and Immunology, Universidade Federal de Minas Gerais, MG, Brazil, according to standard procedures (15) and were used shortly after weaning (21-23 days). Conventional Swiss/NIH mice of the same age and of both sexes were obtained from our colony. $\mathrm{C} 3 \mathrm{H} / \mathrm{HeJ}$ mice were obtained from the animal facility of the Centro de Pesquisas René Rachou (FioCruz, Belo Horizonte, MG, Brazil). L. delbrueckii var. bulgaricus UFV-H2b20 (L. delbrueckii), a strain of human origin, was isolated at Universidade Federal de Viçosa and maintained at $-70^{\circ} \mathrm{C}$ in non-fat reconstituted dry milk. The strain was grown in MRS broth (De Man, Rogosa \& Sharpe, Merck, Brazil) for $18 \mathrm{~h}$ at $37^{\circ} \mathrm{C}$ just before use. Listeria monocytogenes 104035 cells (a kind gift from Dr. Daniel Portnoy, University of Pennsylvania, Philadelphia, PA, USA) were maintained at $-70^{\circ} \mathrm{C}$ in brain heart infusion broth (Merck) containing 20\% glycerol. Before use, the strain was grown overnight in brain heart infusion broth at $37^{\circ} \mathrm{C}$.

Different preparations of $L$. delbrueckii UFV-H2b20 and L. monocytogenes 104035 were used to stimulate cells for the cytokine production assays. All preparations were obtained after washing activated cultures three times in phosphate-buffered saline (PBS, $0.15 \mathrm{M} \mathrm{NaCl}, 10 \mathrm{mM}$ sodium phosphate, $\mathrm{pH}$ 7.3). Live L. delbrueckii was maintained viable until use. Heat-killed $L$. delbrueckii and $L$. monocytogenes were obtained by autoclaving cells for $5 \mathrm{~min}$ at $121^{\circ} \mathrm{C}$. Inactivated L. delbrueckii was obtained by maintaining cells at $56^{\circ} \mathrm{C}$ for $60 \mathrm{~min}$. In order to digest the cell wall, PBS-washed bacteria were suspended in $67 \mathrm{mM}$ PBS, pH 6.2, containing $0.01 \%$ lysozyme (Sigma, USA) and incubated at $37^{\circ} \mathrm{C}$ for $48 \mathrm{~h}$ as described (16).

Monoassociation of mice with $L$. delbrueckii UFV-H2b20

The activated culture of $L$. delbrueckii UFV-H2b20 was centrifuged at $2000 \mathrm{~g}$ at $4^{\circ} \mathrm{C}$ and resuspended in PBS in order to obtain $10^{9}$ colony-forming units $/ \mathrm{mL}$. One hundred microliters of this suspension was inoculated intragastrically into germ-free mice. The success of monoassociation was checked by investigating the number of microorganisms per gram feces. Monoassociated mice were used 7 days after the original inoculum since $L$. delbrueckii numbers in the gut were stable starting 2 days after the inoculum (13). 
Intravenous challenge with $E$. coli

Intravenous challenge with $E$. coli was performed as described previously (13). Briefly, germ-free or monoassociated mice were challenged with $2 \times 10^{7} \mathrm{E}$. coli in the tail vein. Blood samples were collected from the retroorbital plexus of anesthesized animals $(100 \mathrm{mg} / \mathrm{kg}$ ketamine hydrochloride, Dopalen, Division Vetbrands Animal Health, Brazil, and $10 \mathrm{mg} / \mathrm{kg}$ xylazine, Anasedan, Agribrands do Brasil Ltda., Brazil) immediately after injection of $E$. coli $\mathrm{B}_{41}$ (time 0 ) and at $1.5,4$, and $8 \mathrm{~h}$ after injection. Mice were sacrificed after the last blood collection and cytokines were assessed as described below.

\section{Peritoneal and spleen cell cultures}

Mice were inoculated intraperitoneally with thioglycollate and sacrificed 5 days later. Peritoneal cells were collected with RPMI 1640 medium (Sigma). Spleen cells were obtained by maceration of the organ with RPMI 1640. The cell suspensions were centrifuged at $1000 \mathrm{~g}$ for $10 \mathrm{~min}$ and the supernatants discarded. The pellets were resuspended in RPMI 1640 supplemented with $10 \%$ fetal bovine serum (FBS, Cultilab, Brazil) for spleen cells and with $5 \%$ FBS for peritoneal cells. The medium was supplemented with $50 \mathrm{mM}$ 2-mercaptoethanol, 100 $\mathrm{IU} / \mathrm{mL}$ penicillin and $0.1 \mathrm{mg} / \mathrm{mL}$ streptomycin. The final concentration was $2 \times 10^{6}$ cells $/ \mathrm{mL}$ for peritoneal cells and $5 \times 10^{6}$ cells $/ \mathrm{mL}$ for spleen cells. $L$. delbrueckii and $L$. monocytogenes were added to cultures in $100 \mu \mathrm{L}$ at a ratio of 10:1 bacteria per mouse cell in the presence or absence of murine recombinant IFN- $\gamma(75 \mathrm{IU} / \mathrm{mL}$, Pharmigen, USA). L. monocytogenes was used as a positive control since it is a traditional inducer of IL-12 and IFN- $\gamma$ (17). Concanavalin A (ConA, Sigma) was used as positive control in assays for IFN- $\gamma$ production. The cultures were incubated at $37^{\circ} \mathrm{C}$ in a humidified atmosphere containing $5 \% \mathrm{CO}_{2}$ for $48 \mathrm{~h}$.

\section{Cytokine detection}

IL-12 p40 and IFN- $\gamma$ were assayed in culture supernatants or sera by capture ELISA, as described previously (18). TNF- $\alpha$ was measured using WEHI 1640 cells (a kind gift from Dr. Phillip Scott, School of Veterinary Medicine, University of Pennsylvania, PA, USA), as described (19). The sensitivity of the assays was $0.3 \mathrm{ng} / \mathrm{mL}, 16 \mathrm{pg} /$ $\mathrm{mL}$ and $0.1 \mathrm{pg} / \mathrm{mL}$ and for IL-12 p40, IFN- $\gamma$ and TNF- $\alpha$, respectively.

\section{Spleen cell proliferation}

Spleen cell proliferation in response to microbial antigens was assayed by culturing $1 \times 10^{6}$ cells in $200 \mu \mathrm{L}$ RPMI supplemented with $10 \%$ FBS, 0.5 mM 2-mercapto- ethanol, $100 \mathrm{IU} / \mathrm{mL}$ penicillin and $0.1 \mathrm{mg} / \mathrm{mL}$ streptomycin, in 96-well tissue-culture plates in the presence or absence of stimuli. Plates were kept at $37^{\circ} \mathrm{C}$ for 3 days in a humidified chamber in a $5 \% \mathrm{CO}_{2}$ atmosphere, then cultures were pulsed with $0.5 \mu \mathrm{Ci}^{3}[\mathrm{H}]$-thymidine (Sigma). Cells were harvested (Cell Harvester series 4012-Skantron Instrument AS, Norway) onto fiberglass filters. Incorporated radioactivity was measured by scintillation and values of cultures without antigen were subtracted from values obtained from stimulated cultures. ConA at the concentration of $50 \mu \mathrm{g} / \mathrm{mL}$ was used as positive control for proliferation in these assays.

\section{Statistical analysis}

The means of three or more treatments were analyzed statistically by ANOVA, followed by the minimum significant difference test. The calculations were performed with the help of the EPISTAT program (T.L. Gustafson, USA). The means of two treatments were compared by the Student $t$-test (Sigma plot, Scientific Graphing Software, Jandel Corporation, USA). Differences were considered to be statistically significant when $\mathrm{P} \leq 0.05$.

\section{Results}

In order to determine the capacity of L. delbrueckii UFV-H2b20 to stimulate the production of type 1 cytokines, peritoneal cells from germ-free or monoassociated Swiss mice were cultured in the presence of heatkilled cells of $L$. delbrueckii. Heat-killed L. monocytogenes cells were used as positive control (20). L. delbrueckii UFV-H2b20 induced similar levels of IL-12 p40 production by peritoneal cells both in germ-free (Figure 1A) or monoassociated mice (Figure 1B), when compared to L. monocytogenes $(\mathrm{P}>0.05)$. Addition of IFN- $\gamma$ to cultures did not significantly improve the production of IL-12 p40 induced by either $L$. delbrueckii or $L$. monocytogenes heat-killed cells $(P>0.05)$, and had no effect on the production of this cytokine in the absence of bacterial stimuli. IL-12 p40 levels produced by cells from germ-free mice in response to either stimulus were lower than levels produced by cells from monoassociated mice (Figure 1). In order to test the possibility of contamination of our L. delbrueckii preparation with LPS, we stimulated peritoneal cells from $\mathrm{C} 3 \mathrm{H} / \mathrm{HeJ}$ mice, which are hyporesponsive to LPS, with the L. delbrueckii preparation. As can be seen in Figure 2, L. delbrueckii was able to induce high levels of IL-12 p40 by peritoneal cells from LPShyporesponsive mice. We also used three other preparations of L. delbrueckii, i.e., a viable preparation, heatinactivated and heat-killed bacteria and a lysozyme-di- 
gested preparation. Lysozyme-treated cells induced the lowest level of IL-12 p40 when compared with heat-killed, viable and heat-inactivated cells (Figure 2). All other treatments induced IL-12 p40 levels similar to those induced by live $L$. delbrueckii. These results show that the stimulating component of the preparations is not contaminating LPS, and that this component from $L$. delbrueckii cells is heat-stable and may be partially eliminated by treatment with lysozyme.

TNF- $\alpha$ production by peritoneal cells was also analyzed. We found induction of TNF- $\alpha$ production by all of the different preparations of $L$. delbrueckii when cells from Swiss monoassociated mice were used, except for the lysozyme-treated preparation (Figure 3A). Similar amounts of TNF- $\alpha$ were produced by cells from germfree mice tested with live and heat-treated $L$. delbrueckii (Figure 1B). Analogous results were found with peritoneal cells from $\mathrm{C} 3 \mathrm{H} / \mathrm{HeJ}$ mice (Figure $3 \mathrm{~B}$ ), except that in these mice the lysozyme-treated preparation induced TNF- $\alpha$ production.

Spleen cells from monoassociated (Figure 4A), germfree or conventional Swiss mice (Figure 4B) and from $\mathrm{C} 3 \mathrm{H} / \mathrm{HeJ}$ (Figure $4 \mathrm{C}$ ) were cultivated in the presence of different $L$. delbrueckii preparations. A polyclonal mito-
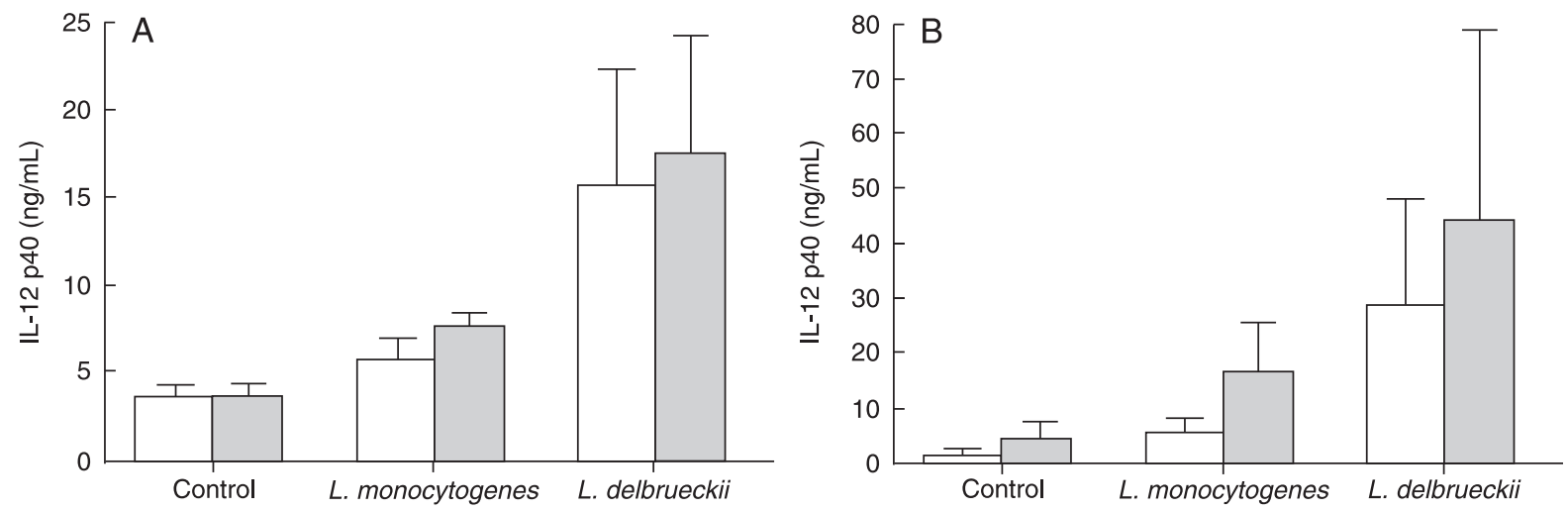

Figure 1. Interleukin-12 (IL-12) p40 production by peritoneal cells from germ-free or Lactobacillus delbrueckii-monoassociated Swiss mice. Thioglycollate-elicited peritoneal cells from $5 \mathrm{germ}$-free (A) or $5 \mathrm{~L}$. delbrueckii-monoassociated mice (B) were cultured for $48 \mathrm{~h}$ with (filled bars) or without (open bars) $75 \mathrm{IU} / \mathrm{mL}$ interferon- $\gamma$ (IFN- $\gamma$ ) and heat-killed L. delbrueckii or heat-killed Listeria monocytogenes. Results for cultures not stimulated with bacteria are also shown (control). IL-12 p40 was assayed in the supernatants by capture ELISA. IL-12 p40 levels produced by cells stimulated with $L$. delbrueckii were statistically different from controls (Student $t$-test). IL-12 p40 levels produced by cells from germ-free mice stimulated with bacterial preparations were lower than those produced by cells from monoassociated mice (Student $t$-test). Results from 5 individually stimulated animals are reported as mean \pm SD. Another experiment was performed with similar results.

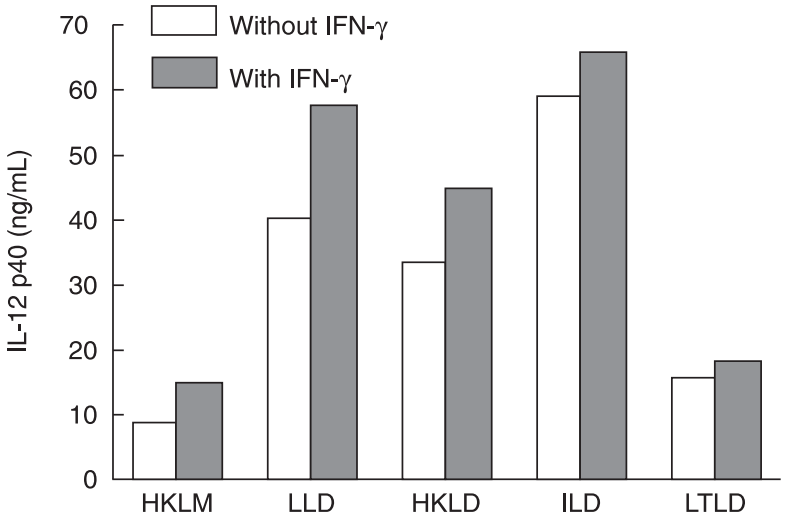

Figure 2. Interleukin-12 (IL-12) p40 production by adherent peritoneal cells pooled from conventional $\mathrm{C} 3 \mathrm{H} / \mathrm{HeJ}$ mice. Thioglycollate-elicited peritoneal cells were cultured for $48 \mathrm{~h}$ with (filled bars) or without (open bars) $75 \mathrm{IU} / \mathrm{mL}$ interferon- $\gamma(\mathrm{IFN}-\gamma)$ and heat-killed Lactobacillus monocytogenes (HKLM), live L. delbrueckii (LLD), heat-killed L. delbrueckii (HKLD), L. delbrueckii heated at $56^{\circ} \mathrm{C}$ for $60 \mathrm{~min}$ (ILD), or lysozyme-treated L. delbrueckii (LTLD). IL-12 p40 was assayed in the supernatants by capture ELISA. Results are reported as one representative experiment of two performed independently. 
gen, ConA, was used as a positive control. Induction of IFN- $\gamma$ after $48 \mathrm{~h}$ of culture with stimuli was assessed. All preparations induced production of IFN- $\gamma$ by spleen cells from monoassociated mice (Figure 4A), including the lysozyme-treated bacterial cells. Similar results were obtained when spleen cells from $\mathrm{C} 3 \mathrm{H} / \mathrm{HeJ}$ mice were used (Figure 4B). Cells from germ-free mice were only tested with live L. delbruekii and ConA (Figure 4B) and, albeit responsive, produced very low levels of IFN- $\gamma$. Taken together, these results confirm the capacity of L. delbrueckii to stimulate type 1 cytokine production.

L. delbrueckii UFV-H2b20 did not induce proliferation of spleen cells from germ-free, monoassociated or conventional Swiss mice (Figure 5 ). These results suggest that NK cells, rather than CD4+ T cells, were the producers of IFN- $\gamma$ when spleen cells were stimulated with $L$. delbrueckii.

In vivo production of type 1 cytokines was also tested. For this purpose, germ-free Swiss mice and mice monoassociated with $L$. delbrueckii UFV-H2b20 by intragastric inoculation were used. After 7 days of monoassociation, mice were challenged with a Gram-negative bacterium injected systemically. The capacity to clear this bacterium from the circulation was previously shown to be improved in monoassociated mice when compared with germ-free and conventional mice (13). Here, we tested the production of cytokines in response to infection with $E$. coli. At the beginning and at the end of the experiment, 90 min after injection of E. coli, we assayed the presence of IL-12 p40 and IFN- $\gamma$ in serum. The serum levels of IL-12 p40 were significantly higher in monoassociated mice than in germfree mice $(P<0.05)$, and comparable to the levels observed for conventional mice (Figure 6).

In order to evaluate the kinetics of appearance of type 1 cytokines in animal sera, we performed experiments in which the cytokines were tested before and at 1.5, 4, and $8 \mathrm{~h}$ after intravenous injection of $E$. coli. We found that the detection of IL-12 p40 in serum of Swiss monoassociated mice preceded the appearance of IFN- $\gamma$ in both germfree and monoassociated mice (Figure 7). The peak of IL$12 \mathrm{p} 40$ in serum occurred $4 \mathrm{~h}$ after the injection of $E$. coli, while at $8 \mathrm{~h}$ after challenge with $E$. coli IFN- $\gamma$ levels were at
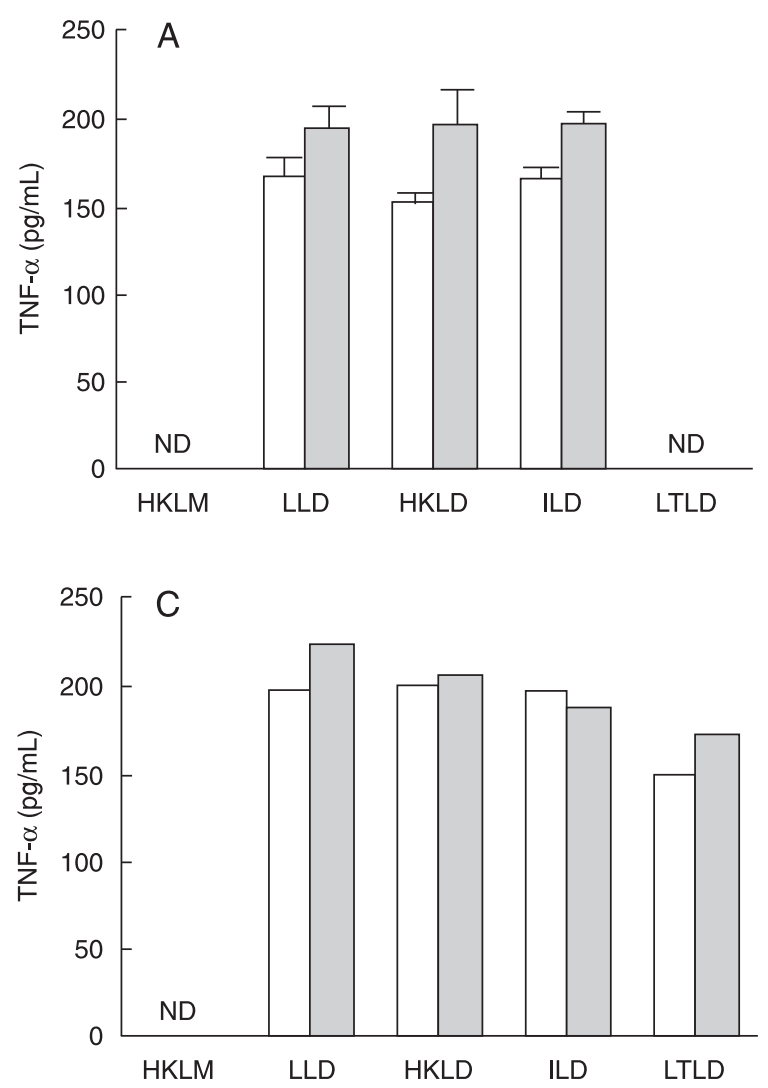

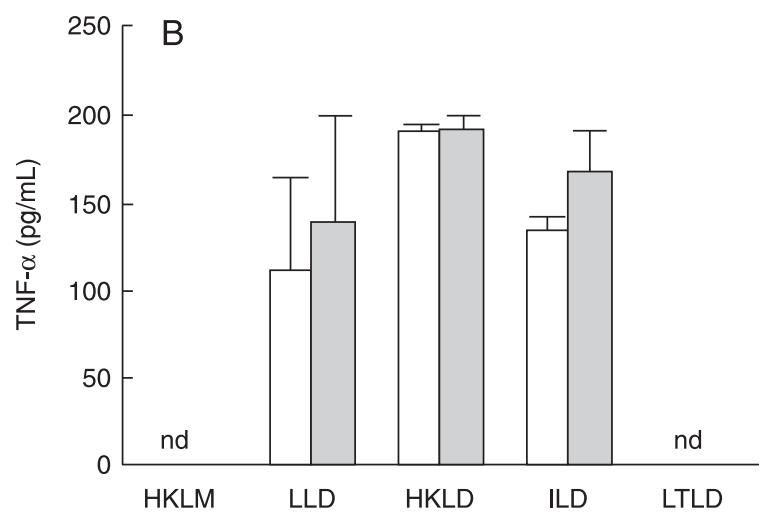

Figure 3. Tumor necrosis factor- $\alpha$ (TNF- $\alpha$ ) production by adherent peritoneal cells in response to Lactobacillus delbrueckii. Thioglycollate-elicited peritoneal cells from 3 Swiss mice monoassociated with $L$. delbrueckii (A), 3 germ-free animals (B) or pooled from $\mathrm{C} 3 \mathrm{H} / \mathrm{HeJ}$ conventional mice $(\mathrm{C})$ were cultured for $48 \mathrm{~h}$ with (filled bars) or without (open bars) $75 \mathrm{IU} / \mathrm{mL}$ interferon- $\gamma$ (IFN- $\gamma$ ) and heat-killed L. monocytogenes (HKLM), live L. delbrueckii (LLD), heat-killed L. delbrueckii (HKLD), L. delbrueckii heated at $56^{\circ} \mathrm{C}$ for $60 \mathrm{~min}$ (ILD), or lysozyme-treated L. delbrueckii (LTLD). TNF- $\alpha$ was assayed in the supernatants using a biological assay. Results are reported as mean $\pm S D$ or as one representative experiment of two performed independently. ND = not detected; nd $=$ not done. No statistical differences were found (Student $t$ test). 

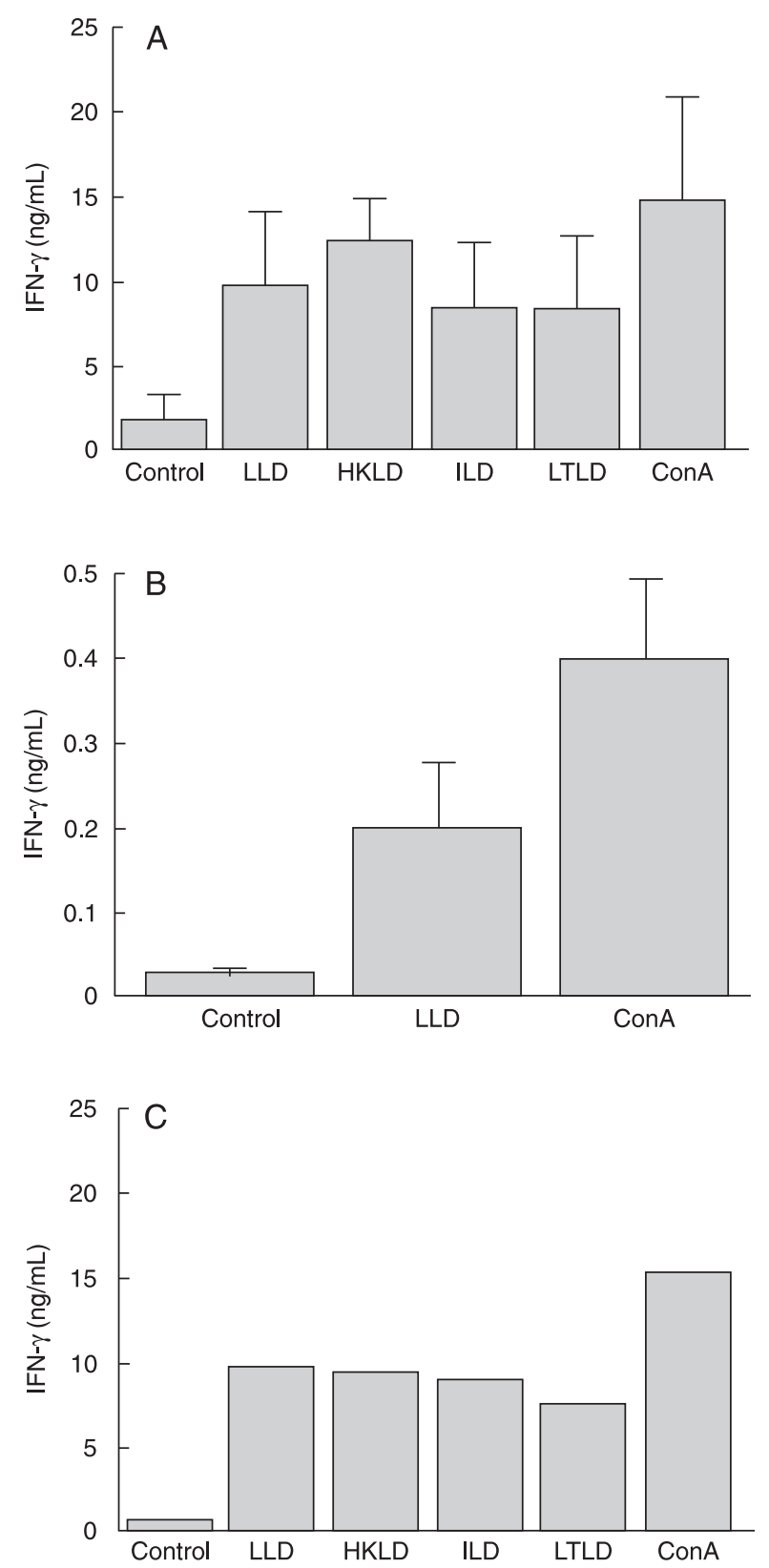

Figure 4. Interferon- $\gamma$ (IFN- $\gamma$ ) production by spleen cells in response to Lactobacillus delbrueckii. Spleen cells from 5 Swiss mice monoassociated with $L$. delbrueckii (A), 5 germ-free animals (B) or pooled from $\mathrm{C} 3 \mathrm{H} / \mathrm{HeJ}$ conventional mice $(\mathrm{C})$ were cultured for $48 \mathrm{~h}$ with live L. delbrueckii (LLD), heat-killed L. delbrueckii (HKLD), L. delbrueckii heated at $56^{\circ} \mathrm{C}$ for $60 \mathrm{~min}$ (ILD), or lysozyme-treated $L$. delbrueckii (LTLD). IFN- $\gamma$ was assayed in the supernatants by capture ELISA. Concanavalin A (ConA) was used as a positive control. In $A$ and $B$, all stimulated cultures were statistically different from control $(P \leq 0.05$, ANOVA followed by the minimum significant difference test). Results are reported as mean $\pm S D$ from one representative experiment of at least two performed independently.

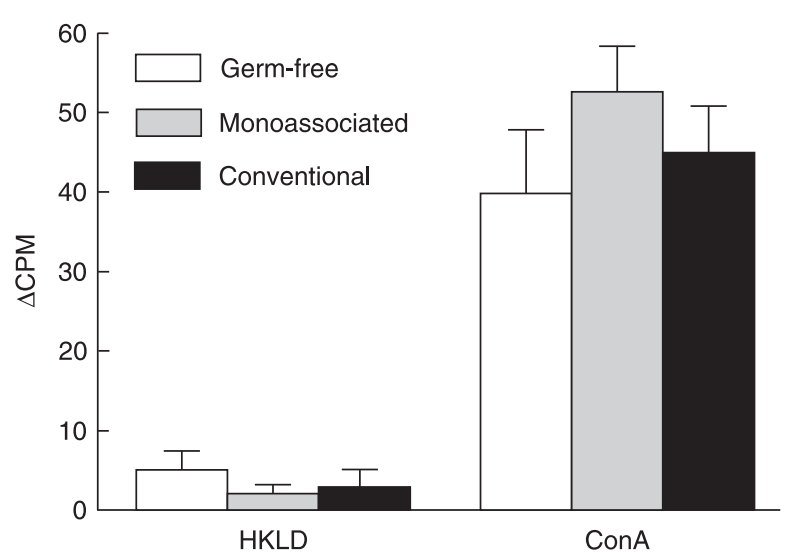

Figure 5. Proliferation of spleen cells in response to Lactobacillus delbrueckii. Cells from germ-free, L. delbrueckii-monoassociated and conventional Swiss mice were stimulated with heatkilled $L$. delbrueckii (HKLD) or concanavalin A (ConA). Single cell suspensions from three mice per group were obtained as described in Material and Methods and cultured in vitro for $24 \mathrm{~h}$ with the stimuli. ${ }^{3}[\mathrm{H}]$-thymidine was added and cells were harvested $18 \mathrm{~h}$ after the pulse. Cultures were performed in triplicate. Bars indicate the average of the counts per minute (CPM $\times 10^{-3}$ ) obtained for each group in the presence of stimuli, after subtraction of values obtained in the absence of stimulus in vitro (cells in culture medium alone). Error bars indicate the SD. All cultures stimulated with ConA were statistically different from the HKLD control ( $P<0.05$, Student $t$-test). Results are from one representative experiment of three performed independently.

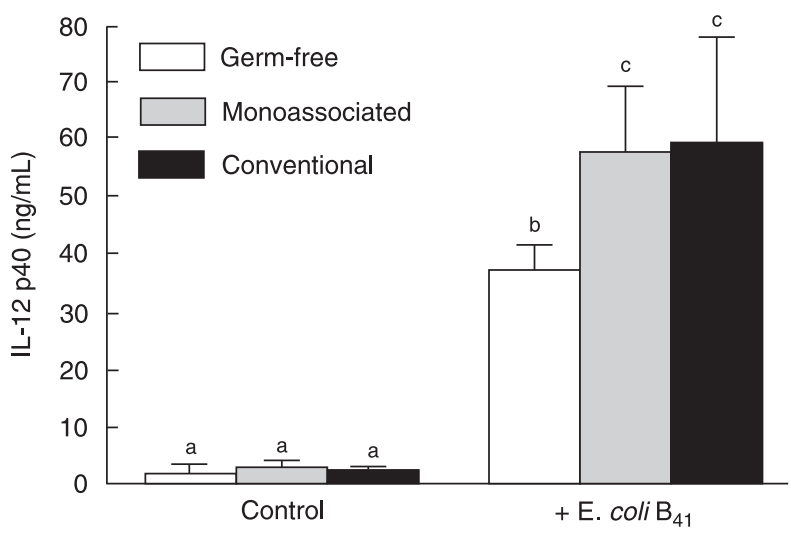

Figure 6. Interleukin-12 (IL-12) p40 levels in sera from mice challenged with Escherichia coli. Germ-free (open bars), Lactobacillus delbrueckii-monoassociated (grey bars) and conventional (black bars) Swiss mice were challenged intravenously with $E$. coli $\mathrm{B}_{41}$ and blood was collected 90 min after the challenge. Data are reported as mean serum cytokine concentration $(\mathrm{ng} / \mathrm{mL}) \pm$ $\mathrm{SD}$. Each bar indicates the mean of 5 mice from one representative experiment of two performed. Different letters indicate significant differences $(P \leq 0.05$, ANOVA followed by the minimum significant difference test). 
the highest level. There was no statistically significant difference between germ-free and monoassociated mice injected with $E$. coli in this experiment (Figure 7A), in contrast with the experiment illustrated in Figure 6 , but more IFN- $\gamma$ was produced by monoassociated mice 4 and $8 \mathrm{~h}$ after injection of $E$. coli (Figure 7B).

\section{Discussion}

A body of evidence has been gathered on the immunostimulatory and immunoregulatory properties of lactobacilli. Studies carried out in our laboratory $(13,21)$ and others $(22,23)$ have shown that monoassociation of mice with lactic acid bacteria renders mice more resistant to infections. A highly significant delayed mortality was observed in germ-free $\mathrm{C} 3 \mathrm{H} / \mathrm{He} / \mathrm{Oujco}$ mice monoassociated with $L$. acidophilus and infected with Salmonella enterica var. enterica serovar typhimurium (22). Similarly, Swiss/NIH mice monoassociated with L. delbrueckii UFV $\mathrm{H} 2 \mathrm{~b} 20$ were also protected against infection with $S$. typhimurium (21). L. delbrueckii-monoassociated animals cleared $E$. coli from the blood stream more efficiently than germ-free mice (13).

Several investigators have demonstrated effects of lactobacilli on cells of the immune system that would explain this improved resistance to infection. Hence, intravenous injection of $L$. casei has been shown to improve NK cell cytotoxicity (24) in vitro. Intraperitoneal inoculation of $L$. delbrueckii or $L$. casei, as well as ingestion of $L$. casei, increases the phagocytic and bactericidal activity of peritoneal and liver macrophages $(25,26)$. In a previous study, we demonstrated the improvement of host mononuclear phagocytic activity after monoassociation of Swiss germ-free mice with viable and heat-killed $L$. delbrueckii UFV-H2b20. Improved phagocytic activity was demonstrated both by the increase clearance of a Gramnegative bacterium inoculated intravenously and by a 2fold increase in the number of Küpffer cells, which are responsible for the clearance of circulating bacteria (13). We and others had also shown that human cells respond to $L$. delbrueckii by producing inflammatory cytokines. Galdeano and Perdigón (27) reported an increased expression of the pro-inflammatory cytokines TNF- $\alpha$, IL-12 and IL-2 in the gut villi of mice given several viable and inviable Lactobacillus strains, including L. delbrueckii. VSL \#3, a bacterial probiotic cocktail that includes $L$. delbrueckii in its formula, was capable of inducing IL-12 p70 production in bone marrow-derived murine dendritic cells stimulated for an overnight period (1). Moreover, peripheral blood mononuclear cells from healthy individuals stimulated with heat-killed L. delbrueckii produced elevated levels of IL-12, IFN- $\gamma$ and TNF- $\alpha$ but not of IL-10. IFN- $\gamma$ production was IL-12-dependent and NK cells were the main source. Furthermore, peripheral blood mononuclear cells infected with Leishmania amazonensis, an intracellular parasite, presented elevated microbicidal activity when co-incubated with $L$. delbrueckii. Finally, $L$. delbrueckii was capable of inducing in vitro differentiation of L. amazonensis-specific Th1 cells (28). Inflammatory
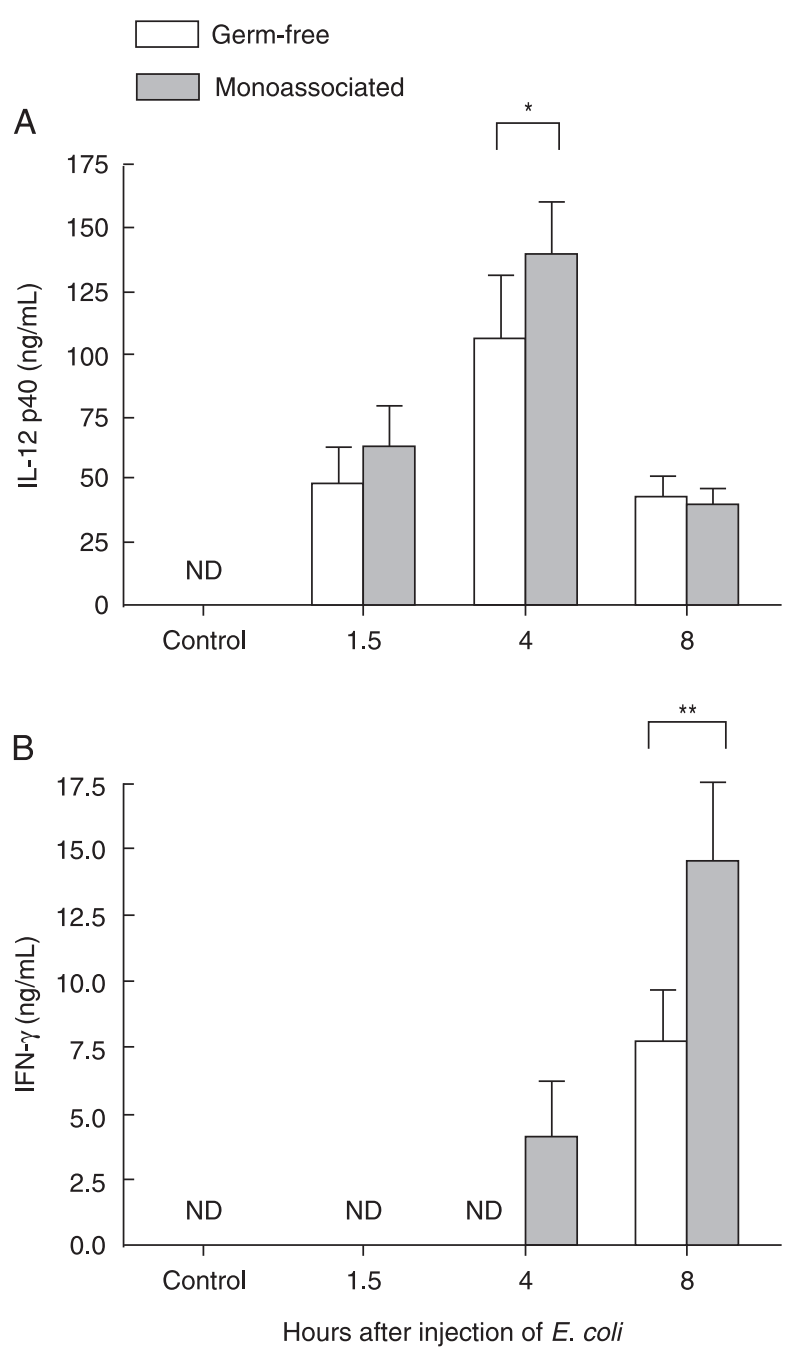

Figure 7. Interleukin-12 (IL-12) p40 and interferon- $\gamma$ (IFN- $\gamma$ ) levels in sera of mice challenged with Escherichia coli. Sera from germ-free (open bars) or Lactobacillus delbrueckii monoassociated (filled bars) mice challenged intravenously with $E$. coli $\mathrm{B}_{41}$ were collected at the indicated times and cytokines were assayed. Control mice were not injected with E. coli. Data are reported as mean serum cytokine concentration $(\mathrm{ng} / \mathrm{mL}) \pm S D$. Each bar indicates the mean of 5 mice from one experiment representative of two performed. ${ }^{*} \mathrm{P}=0.058 ;{ }^{*} \mathrm{P}<0.05$ (Student $t$-test). ND = not detected. 
cytokines such as IL-12, IFN- $\gamma$ and TNF- $\alpha$ have been implicated in resistance to several pathogens, including L. monocytogenes, Salmonella enterica var. thyphimurium (17,29-31). Therefore, if a candidate probiotic strain is to have an effect against infections, the property of inducing these inflammatory cytokines is desirable.

In this paper we show that live, heat-killed and heattreated $\left(56^{\circ} \mathrm{C}\right)$ L. delbrueckii UFV-H2b20 preparations induce high levels of IL-12 p40, TNF- $\alpha$ and IFN- $\gamma$ production in vitro. Induction of both TNF- $\alpha$ and IFN- $\gamma$ by $L$. acidophilus was comparable to that of murine cells exposed to other stimuli $(18,32)$. The in vitro induction of IL12 p40 observed in our experiments was higher than that induced by $L$. monocytogenes, and similar to or higher than the results obtained for other antigenic stimuli (Figures 1 and 2) (33-36). The induction of IL-12 p40 and TNF- $\alpha$ production by peritoneal cells from $\mathrm{C} 3 \mathrm{H} / \mathrm{HeJ}$ mice, which are hyporesponsive to LPS, confirms the absence of contamination of $L$. delbrueckii UFV-H2b20 preparations with LPS (Figures 1 and 2). Moreover, all our lactobacillus preparations induced a similar production of IL12 p40, TNF- $\alpha$ and IFN- $\gamma$, indicating that the molecules that induce these cytokines are heat-stable and mostly lysozyme-resistant. The only instances in which lysozyme treatment abolished (Figure 3A) or diminished (Figure 2) cytokine production were the production of IL-12 p40 by macrophages from $\mathrm{C} 3 \mathrm{H} / \mathrm{HeJ}$ mice and the production of TNF- $\alpha$ by macrophages from monoassociated mice. The reasons for these two results are unknown. However, since the results for $\mathrm{C} 3 \mathrm{H} / \mathrm{HeJ}$ mice are from pools of cells, no statistical analysis was performed. Macrophages from germ-free mice have been shown to be less reactive (and to produce less inflammatory cytokines) than macrophages from conventional mice in several different models (13,3739), a result consistent with the fact that macrophages from germ-free mice produced lower levels of IL-12 p40 when compared to monoassociated mice. However, macrophages from germ-free mice produced similar levels of TNF- $\alpha$ when stimulated with bacterial preparations. Macrophages from germ-free mice have been previously shown to produce lower levels or TNF- $\alpha$ in response to LPS than macrophages from conventional mice (39). The differences in these results might be due to the fact that germ-free mice respond differently to Gram-negative and Gram-positive stimuli. IFN- $\gamma$ production by spleen cells from germ-free mice was also significantly lower than the production by spleen cells from monoassociated mice, but spleen cells from germ-free mice were still responsive to the stimulus with the bacterial preparations. The lower production of IL-12 p40 is consistent with the lower production of IFN- $\gamma$ in these mice (17). Taken together, our data indicate that monoassociation primed macrophages to the production of IL-12 p40.

Takeda et al. (40) demonstrated that L. delbrueckii LA158 cell wall acid polysaccharides were mitogenic for C57BL/6 spleen cells and for BALB/c Peyer's patch cells. Here we show that heat-killed L. delbrueckii UFV-H2b20 did not stimulate murine spleen cell proliferation (Figure 5), which suggest differences in the cell wall composition between strains of the same bacterial species. Fractions of cell walls from UFV-H2b20 should be tested, however, in order to clarify this issue. Taken together, their results and ours suggest that NK cells, rather than CD4+ T cells, are the producers of IFN- $\gamma$ when spleen cells are stimulated with L. delbrueckii.

We had previously demonstrated that monoassociated mice clear $E$. coli from their circulation more efficiently than germ-free mice (13). Here, we investigated if monoassociation with $L$. delbrueckii would have further influence on the response of the mouse to a systemic infection. We found marginal differences in IL-12 p40 among groups (Figures 6 and 7B), which were statistically significant in two of four experiments at 90 min after injection of $E$. coli. As seen in Figure 7B, systemic IFN- $\gamma$ production is accelerated when monoassociated mice are challenged with $E$. coli. This acceleration might be taken as evidence for a higher, albeit small, increase in the production of biologically active IL-12 (17). Therefore, at least as far as IFN- $\gamma$ levels are concerned, the immune response to a systemic infection is influenced by the presence of $L$. delbrueckii in the gut since in mice monoassociated with $L$. delbrueckii the IFN- $\gamma$ response to a pathogen was more precocious than in germ-free mice (Figure 7B). The use of germ-free animals has the obvious drawback of being an artificial model: the effect of $L$. delbrueckii in a more natural environment where the probiotic would interact with the indigenous microbiota is not considered when one uses germ-free animals. Moreover, germ-free mice are thought to have an "immature" immune system. However, germ-free animals have the also obvious advantage of allowing the study of the effect of the microorganism by itself on the system. Taken together, our data raise the question of whether L. delbrueckii would promote resistance to organisms that are controlled by a type 1 response.

The present data demonstrate that $L$. delbrueckii UFV$\mathrm{H} 2 \mathrm{~b} 20$ induces the production of type 1 cytokines. More interestingly, our results suggest that the induction of a pro-inflammatory response by $L$. delbrueckii UFV-H2b20 may not require the feeding of viable cells to the host, as is generally thought to be required for the beneficial effects of probiotics. If this holds true in vivo, a preparation con- 
taining non-inviable organisms would have obvious commercial advantages. This issue is currently under investigation.

\section{Acknowledgments}

We wish to thank Dr. Ricardo Tostes Gazzinelli (Universidade Federal de Minas Gerais) for the $\mathrm{C} 3 \mathrm{H} / \mathrm{HeJ}$ mice, for assistance in the IL-12 p40 detection experiments and for a general discussion of our results. We are thankful to Dr. Célia Alencar de Morais (Universidade Federal de Viçosa) for supplying L. delbrueckii UFV-H2b20 and to Antonio Mesquita Vaz, Maria Gorete Barbosa Dias and Ronilda Maria de Paula (in memoriam) (Universidade Federal de Minas Gerais) for animal care.

\section{References}

1. Drakes M, Blanchard T, Czinn S. Bacterial probiotic modulation of dendritic cells. Infect Immun 2004; 72: 3299-3309.

2. Walker R, Buckley M. Probiotic microbes: the scientific basis. A report from the American Academy of Microbiology. Forthcoming. http://www.asm.org.

3. Calcinaro F, Dionisi S, Marinaro M, Candeloro P, Bonato V, Marzotti S, et al. Oral probiotic administration induces interleukin-10 production and prevents spontaneous autoimmune diabetes in the non-obese diabetic mouse. Diabetologia 2005; 48: 1565-1575.

4. Ezendam J, van Loveren H. Lactobacillus casei Shirota administered during lactation increases the duration of autoimmunity in rats and enhances lung inflammation in mice. Br J Nutr 2008; 99: 83-90.

5. Maassen CB, Claassen E. Strain-dependent effects of probiotic lactobacilli on EAE autoimmunity. Vaccine 2008; 26: 2056-2057.

6. Filho-Lima JV, Vieira EC, Nicoli JR. Antagonistic effect of Lactobacillus acidophilus, Saccharomyces boulardii and Escherichia coli combinations against experimental infections with Shigella flexneriand Salmonella enteritidis subsp. typhimurium in gnotobiotic mice. J Appl Microbiol 2000; 88: 365370.

7. Perdigon G, de Macias ME, Alvarez S, Oliver G, de Ruiz Holgado AP. Systemic augmentation of the immune response in mice by feeding fermented milks with Lactobacillus casei and Lactobacillus acidophilus. Immunology 1988; 63: 17-23.

8. Haller D, Blum S, Bode C, Hammes WP, Schiffrin EJ. Activation of human peripheral blood mononuclear cells by nonpathogenic bacteria in vitro: evidence of NK cells as primary targets. Infect Immun 2000; 68: 752-759.

9. Ibnou-Zekri N, Blum S, Schiffrin EJ, von der Weid T. Divergent patterns of colonization and immune response elicited from two intestinal Lactobacillus strains that display similar properties in vitro. Infect Immun 2003; 71: 428-436.

10. Matsuguchi T, Takagi A, Matsuzaki T, Nagaoka M, Ishikawa $\mathrm{K}$, Yokokura T, et al. Lipoteichoic acids from Lactobacillus strains elicit strong tumor necrosis factor alpha-inducing activities in macrophages through Toll-like receptor 2. Clin Diagn Lab Immunol 2003; 10: 259-266.

11. Trinchieri G. Interleukin-12 and the regulation of innate resistance and adaptive immunity. Nat Rev Immunol 2003; 3: 133-146.

12. Agostinho SMM. Comportamento de L. acidophilus $\mathrm{H} 2 \mathrm{~b} 20$ sob condições do trato digestivo in vitro e efeito de métodos de preservação em sua atividade. [Master's thesis]: Univer- sidade Federal de Viçosa; 1988.

13. Neumann E, Oliveira MA, Cabral CM, Moura LN, Nicoli JR, Vieira EC, et al. Monoassociation with Lactobacillus acidophilus UFV-H2b20 stimulates the immune defense mechanisms of germfree mice. Braz J Med Biol Res 1998; 31: 15651573.

14. Neves JTM, Floresta F, Moraes CA. Partial characterization of ribosomal operons of Lactobacillus delbrueckii UFV H2b20. Braz J Microbiol 2005; 36: 177-182.

15. Pleasants JR. Gnotobiotics. In: Melby EC Jr, Altman NH (Editors), Handbook of laboratory animal science. 1st edn. Cleveland: CRC Press; 1974. p 119-174.

16. Namba Y, Hidaka Y, Taki K, Morimoto T. Effect of oral administration of lysozyme or digested bacterial cell walls on immunostimulation in guinea pigs. Infect Immun 1981; 31: 580-583.

17. Hsieh CS, Macatonia SE, Tripp CS, Wolf SF, O'Garra A, Murphy KM. Development of TH1 CD4+ T cells through IL12 produced by Listeria-induced macrophages. Science 1993; 260: 547-549.

18. Oliveira MA, Santiago HC, Lisboa CR, Ceravollo IP, Trinchieri G, Gazzinelli RT, et al. Leishmania sp: comparative study with Toxoplasma gondii and Trypanosoma cruzi in their ability to initialize IL-12 and IFN-gamma synthesis. Exp Parasitol 2000; 95: 96-105.

19. Lattime EC, Stoppacciaro A, Stutman O. Limiting dilution analysis of TNF producing cells in $\mathrm{C} 3 \mathrm{H} / \mathrm{HeJ}$ mice. $\mathrm{J}$ Immunol 1988; 141: 3422-3428.

20. Hsieh CS, Macatonia SE, O'Garra A, Murphy KM. T cell genetic background determines default $\mathrm{T}$ helper phenotype development in vitro. J Exp Med 1995; 181: 713-721.

21. Moura LN, Neumann E, Vieira LQ, Nicoli JR. Protection by Lactobacillus UFV-H2b20 against experimental oral infection with Salmonella enterica subp. enterica ser typhimurium in gnotobiotic and conventional mice. Braz J Microbiol 2001; 32: 66-69.

22. Bernet-Camard MF, Lievin V, Brassart D, Neeser JR, Servin $\mathrm{AL}$, Hudault $\mathrm{S}$. The human Lactobacillus acidophilus strain LA1 secretes a nonbacteriocin antibacterial substance(s) active in vitro and in vivo. Appl Environ Microbiol 1997; 63: 2747-2753.

23. Kabir AM, Aiba Y, Takagi A, Kamiya S, Miwa T, Koga Y. Prevention of Helicobacter pylori infection by lactobacilli in a gnotobiotic murine model. Gut 1997; 41: 49-55.

24. Kato I, Yokokura T, Mutai M. Augmentation of mouse natural killer cell activity by Lactobacillus casei and its surface 
antigens. Microbiol Immunol 1984; 28: 209-217.

25. Perdigon G, Nader de Macias ME, Alvarez S, Oliver G, Pesce de Ruiz Holgado AA. Enhancement of immune response in mice fed with Streptococcus thermophilus and Lactobacillus acidophilus. J Dairy Sci 1987; 70: 919-926.

26. Sato K, Saito H, Tomioka H. Enhancement of host resistance against Listeria infection by Lactobacillus casei: activation of liver macrophages and peritoneal macrophages by Lactobacillus casei. Microbiol Immunol 1988; 32: 689-698.

27. Galdeano CM, Perdigon G. Role of viability of probiotic strains in their persistence in the gut and in mucosal immune stimulation. J Appl Microbiol 2004; 97: 673-681.

28. Castanheira LG, Castro JM, Martins-Filho OA, Nicoli JR, Vieira LQ, Afonso LC. Lactobacillus delbrueckii as a potential skin adjuvant for induction of type 1 immune responses. Front Biosci 2007; 12: 1300-1307.

29. Dunn PL, North RJ. Early gamma interferon production by natural killer cells is important in defense against murine listeriosis. Infect Immun 1991; 59: 2892-2900.

30. Nakane A, Numata A, Chen Y, Minagawa T. Endogenous gamma interferon-independent host resistance against $L$ isteria monocytogenes infection in CD4+ T cell- and asialo GM1+ cell-depleted mice. Infect Immun 1991; 59: 34393445.

31. Eckmann L, Kagnoff MF. Cytokines in host defense against Salmonella. Microbes Infect 2001; 3: 1191-1200.

32. Vieira LQ, Goldschmidt M, Nashleanas M, Pfeffer K, Mak T, Scott $P$. Mice lacking the TNF receptor p55 fail to resolve lesions caused by infection with Leishmania major, but control parasite replication. J Immunol 1996; 157: 827-835.

33. Vieira LQ, Hondowicz BD, Afonso LC, Wysocka M, Trinchieri G, Scott P. Infection with Leishmania major induces interleu- kin-12 production in vivo. Immunol Lett 1994; 40: 157-161.

34. Wysocka M, Kubin M, Vieira LQ, Ozmen L, Garotta G, Scott $P$, et al. Interleukin-12 is required for interferon-gamma production and lethality in lipopolysaccharide-induced shock in mice. Eur J Immunol 1995; 25: 672-676.

35. Bost KL, Clements JD. Intracellular Salmonella dublin induces substantial secretion of the 40-kilodalton subunit of interleukin-12 (IL-12) but minimal secretion of IL-12 as a 70kilodalton protein in murine macrophages. Infect Immun 1997; 65: 3186-3192.

36. Kato I, Tanaka K, Yokokura T. Lactic acid bacterium potently induces the production of interleukin-12 and interferon-gamma by mouse splenocytes. Int $\mathrm{J}$ Immunopharmacol 1999; 21: 121-131.

37. Nicaise $P$, Gleizes A, Sandre C, Kergot R, Lebrec H, Forestier $F$, et al. The intestinal microflora regulates cytokine production positively in spleen-derived macrophages but negatively in bone marrow-derived macrophages. Eur Cytokine Netw 1999; 10: 365-372.

38. Rodrigues AC, Cara DC, Fretez SH, Cunha FQ, Vieira EC, Nicoli JR, et al. Saccharomyces boulardii stimulates slgA production and the phagocytic system of gnotobiotic mice. $J$ Appl Microbiol 2000; 89: 404-414.

39. Souza DG, Vieira AT, Soares AC, Pinho V, Nicoli JR, Vieira $L Q$, et al. The essential role of the intestinal microbiota in facilitating acute inflammatory responses. J Immunol 2004; 173: $4137-4146$.

40. Takeda K, Saito T, Kitazawa H, Uemura J, Itoh T. Mitogenic activity of whole cells and cell wall components of Lactobacillus delbrueckii group lactic acid bacteria on murine spleen and Peyer's patch cells. Milchwissenschaft 2007; 52: 21-25. 